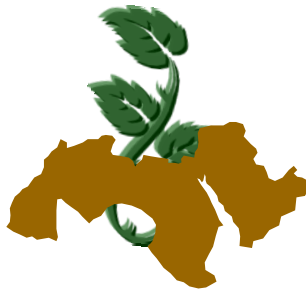

Arab Univ. J. Agric. Sci., Ain Shams Univ., Cairo, 16(1), 87-96, 2008

\title{
CHEMICAL AND TECHNOLOGICAL EVALUATION OF SOME SWEET POTATO VARIETIES
}

\author{
El-Bastawesy Amal ${ }^{1}$, M.; Lobna A. Hareedy ${ }^{1}$ and Mervat M. EL-Far ${ }^{2}$ \\ 1- Food Technology Res. Institute, Agric. Res. Center, Giza, Egypt. \\ 2- Agricultural Genetic Engineering Research Institute, Agric. Res. Center, 12619, Giza, Egypt
}

Keywords: Sweet potato, Creamy and yellow flesh, Chemical characteristics, $\beta$-carotene, Sweet potato products

\begin{abstract}
This investigation was carried out to evaluate the chemical characteristics of new eight sweet potato varieties namely, CEMSA 74-228, SANTO AMARA, NC 1525 and KEMB 37 (creamy flesh) and JAPON TRESMESINO, LO 323, TAINUNG 64 and BEAUREGARD (yellow flesh ), and study their suitability for processing. The obtained results reveal that SANTO AMARA and KEMB37 varieties were the best ones having the highest content of chemical constituents compared with those of the other studied creamy flesh sweet potato varieties. Moreover, 140 days from planting was the best harvesting time that achieved the highest chemical characteristics. All selected creamy sweet potato varieties had adequate minerals contents especially, KEMB 37 followed by NC 1525 and CEMSA 74-228 then SANTO AMARA varieties that could be considered good sources of minerals for human nutrition. Yellow flesh sweet potatoes have been recognized as valuable sources of carbohydrates, protein, dietary fibers and could be considered as good sources of both vitamin $\mathrm{C}$ and total carotenoids. Moreover, TAINUNG 64 and LO 323 were found to be good sources of $\beta$ carotene (pro- vitamin A). The more suitable harvesting time for yellow sweet potato varieties, which recorded the highest levels of essential elements, was 140 days from planting. On the other hand, TAINUNG 64 variety could be considered the best one compared to the other examined varities. The most suitable varieties that having good quality attributes for processing were SANTO
\end{abstract}

AMARA and KEMB 37 as creamy flesh and TAINUNG 64 and BEAUREGARD as yellow flesh sweet potato varieties. Moreover, these varieties could be successfully used in the production of new and untraditional sweet potato products.

\section{INTRODUCTION}

Sweet potato (Ipomoea batatas L.), Family Convolvulaceae is one of the important vegetable crops grown in Egypt for local consumption. Furthermore, sweet potatoes are considered the sixth largest cultivar grown all over the world. Recently, new sweet potato varieties with a good eating and manufacturing properties were developed. In Egypt, sweet potatoes are widely used primarily as a popular human food receiving an increasing attention as fodder for livestock. Recent interest has been generated in new and improved uses for sweet potatoes including convenience consumer foods. New technological processing of sweet potatoes have developed such as, french fried and extruded products to agree with the consumer requirements (Walter and Hoover, 1986). Sweet potato is an inexpensive caloric source for the expanding mass of low income group. Also, sweet potatoes have been recognized as valuable sources of carbohydrates, protein, dietary fibers, vitamin $\mathrm{C}$, carotenoids and minerals such as potassium, sodium, magnesium and moderate quantities of calcium and phosphorus (Picha, 1985; AbdelMagied et al 1992; Abdel-Ghani et al 1997 and 2001; Mohamed, 1997; Rashwan, 1998 and Zaki, 2000 and 2007). Furthermore, both yellow and creamy flesh sweet potatoes are considered good sources of vitamin C (Woolfe, 1992). A great interest has recently been focused on sweet potatoes 
especially, the yellow flesh sweet potatoes, which are characterized with their high contents of $\beta$ carotene. $\beta$-carotene, is one of the most widely investigated micronutrients of fruits and vegetables, has been associated with a reduced risk of cancer (Tavani and La Vecchia, 1995). Some carotenoids, besides provitamin A activity, have other functions such as, antioxidative effect, enhancers of the immune response and some of them are involved in the cell communication (Ruel, $\boldsymbol{e t}$ al 2005).

Accordingly, this study was a trial to evaluate some new varieties of sweet potatoes depending upon their chemical properties to select the most suitable ones for the production of untraditional sweet potato products.

\section{MATERIALS AND METHODS}

\section{Materials}

New eight sweet potato varieties namely, CEMSA 74-228 , SANTO AMARA, NC 1525 and KEMB 37 ( creamy flesh ) and JAPON TRESMESINO, LO 323, TAINUNG 64 and BEAUREGARD ( yellow flesh ) were selected from fourteen varieties delivered to the Agricultural Genetic Engineering Research Institute (AGERI) to be evaluated for yield and quality under the Egyptian conditions. Plants were cultivated in (AGERI) experimental field ARC and harvested over three times (after 140, 160 and 180 days from planting). Also, the highest productive varieties were selected to be evaluated for their chemical composition and organoleptic properties.

\section{Methods}

\section{1- Preparation of sweet potato products}

Sweet potato roots were sorted, cleaned and washed, then divided into three parts. The first part was blanched at $70^{\circ} \mathrm{C}$ for $40 \mathrm{~min}$., the second was baked in an oven at $320^{\circ} \mathrm{C}$ for $30 \mathrm{~min}$. and the third was peeled and cut mechanically into slices (4 mm thickness ) to chips then washed and deep fried in hot sunflower oil at $180 \pm 5^{\circ} \mathrm{C}$ using an automatically temperature control machine.

\section{2- Preparation of sweet potato powder}

Selected sweet potato roots were cleaned, washed, peeled and micanically crushed then dried in an air circulated oven at $60{ }^{\circ} \mathrm{C}$ for $12 \mathrm{hrs}$. to moisture content less than $10 \%$. The dried sweet potato roots were milled using Braun mill machine, sieved through 21 mesh screen, packaged in polyethylene bags and stored in refrigerator $\left(4 \pm 1^{\circ} \mathrm{C}\right)$ for analysis.

\section{3 - Analytical methods}

- Moisture, total solids, ash, starch, crude fibers, total lipids and crude protein contents were determined according to the A.O.A.C (2000). Total soluble solids, reducing sugars, total carotenoids and ascorbic acid were determined by the methods described by Ranganna (1979). Total carbohydrates were determined by difference. Energy values protein digestibility and Retinol equivalent (RE) were determined by the methods described by James (1995). - $\beta$-carotene was determined using HPLC Hewlett Packard, Series, Auto Samlar ,HP 1050, Pump HP1100, RI HP1047A, Degasser HP1050, U.V detector, wave length 450nm, Flow rat $1 \mathrm{ml} / \mathrm{min}$., Temp. $35^{\circ} \mathrm{C}$ according to the method described by Pupin, et al (1999). - Minerals (potassium, sodium, calcium, iron, manganese and zinc) were determined by dry ashing using atomic absorption PYe Unican Spectrophotometer Sp. England, as mentioned by Kasai, et al (1997).

\section{4- Organoleptic properties}

Sensory attributes (crispness, freshness, color, taste and odor) of examined sweet potato products were evaluated directly after preparation by more than ten panelists in the Food Tech. Res. Inst. according to the method of Lindley, et al (1993).

\section{5- Statistical analysis}

The results were analyzed by analysis of variance (ANOVA) using the procedure by Statistical Analysis System (SAS) program according to Steel and Torrie (1980). Significant differences were determined at the level $p \geq 0.05$.

\section{RESULTS AND DISCUSSION}

\section{1- Effect of harvesting time on chemical com- position and minerals content of selected sweet potato varieties}

The effect of harvesting time (after 140, 160 and 180 days), on the chemical composition of the eight studied sweet potato varieties was studied and the results are shown in Tables $(1,2,3$ and 4). 


\section{1- Chemical composition of creamy flesh va- rieties}

Table (1) shows the approximate chemical composition of selected creamy flesh sweet potato varieties through three different harvesting times. The obtained data reveal that the moisture content ranged from 4.45 to $7.93 \%$ on dry weight bases for all varieties and the difference may be depending upon the extent of drying. Total solids content decreased gradually with increasing the harvesting times for all varieties and KEMB 37 variety had the highest total solids and total soluble solids contents (38.90 and $21.60 \%$, respectively), followed by SANTO AMARA (36.60 and $19.60 \%$, respectively). All studied sweet potato varieties showed the similar trends for starch content. Otherwise, 160 days was the best harvesting time that recorded the highest level of starch for all varieties. As shown in the same table, it could be noticed that increasing trend of crude fibers content of all varieties was in parallel with increasing the harvesting time. SANTO AMARA variety contained the highest amount of crude fibers (8.85\%), followed by KEMB 37 and CEMSA74-228 varieties (6.69 and 6.49\%, respectively). Moreover, both totals carbohydrates and lipids contents decreased with increasing the harvesting time and KEMB37 variety recorded high contents of them (75.80 and 3.35\%, respectively) (Table, 1). From the aforementioned data, no difference was found in protein content $(5.72$ to $7.66 \%)$ of all sweet potato varieties, but KEMB37 variety had the highest protein content. These results are in agreement with those reported by Abdel-Ghani $\boldsymbol{e t}$ al (2001) and Zaki (2000 and 2007). The energy values of all varieties ranged from 318.37 to $357.79 \mathrm{Kcal} / 100 \mathrm{~g}$ dry matter. Furthermore, a decreasing trend in ascorbic acid content of all varieties was observed with elongation of the harvesting time. CEMSA74-228 and SANTO AMARA varieties had the highest contents of ascorbic acid (6.93 and $6.44 \mathrm{mg} / 100 \mathrm{gm}$, respectively). These results are in accordance with those reported by Woolfe (1992); Abdel-Ghani et al (1997 \& 2001) and Zaki ( 2000).

Finally, from data presented in Table (1), it could be clearly concluded that SANTO AMARA and KEMB37 were the best varieties having the highest content of chemical constituents compared with those of other creamy flesh sweet potato varieties. Besides, 140 days from planting was the best harvesting time that achieved the highest qualities of chemical composition.

\section{2- Minerals contents of selected creamy flesh varieties}

Data in Table (2) show the effect of harvesting time on minerals content of creamy flesh sweet potato roots. Potassium, sodium, calcium, iron, manganese and zinc, considered as the most important minerals for human nutrition, were determined and the obtained results reveal considerable variations in the minerals content of all selected varieties depending upon the harvesting time. With regard to the harvesting time, ash content of creamy sweet potato varieties reached the highest levels after 180 days of planting for all samples. This may be attributed to the continuous translocation process of metabolites containing minerals from shoots to the tuberous roots with elongation of the harvesting time. Creamy flesh sweet potato varieties were characterized by high levels of some minerals such as potassium, calcium, iron and moderate amounts of zinc. Potassium was found to be the highest element level in all tested varieties compared with those of the other estimated elements. But, its content decreased with increaseing the harvesting time. These results are in accordance with those reported by Picha (1985) and Abdel- Magied et al (1992). Both $\mathrm{Ca}$ and $\mathrm{Mn}$ contents decreased with increasing the harvesting time and 140 days from planting was the best harvesting time. KEMB 37 variety had the highest level of Ca content (121.31 mg/100 gm ), followed by NC 1525 and SANTO AMARA varieties being 71.64 and $62.13 \mathrm{mg} / 100 \mathrm{gm}$, respectively. Moreover, in creamy flesh sweet potato roots, iron and zinc contents were found in high levels after 160 days from planting and ranged from 38.96 to 22.80 and 12.98 to $4.48 \mathrm{mg} / 100 \mathrm{gm}$, respectively. KEMB 37 variety had the highest level of zinc content followed by NC 1525 and SANTO AMARA varieties being 8.14 and $7.38 \mathrm{mg} / 100$ gm, respectively. But CEMSA 74-228 sweet potato variety recorded the highest levels of Fe 38.96 $\mathrm{mg} / 100$ gm (Table, 2). Recommended daily allowances (RDA), of potassium for children and adults are 1650 and $1875 \mathrm{mg} /$ day, respectively. As well as, RDA for sodium and calcium are 450, 800 and 900, $1200 \mathrm{mg} /$ day for children and adults, respectively (Anonymous, 1980). From the aforementioned data, it could be concluded that all selected sweet potatoes had adequate minerals contents especially, KEMB 37 followed by NC 1525 and CEMSA 74- 228 then SANTO AMARA sweet potato varieties and could be considered as good sources of minerals for human nutrition. 
El-Bastawesy Amal; Lobna Hareedy and Mervat El-Far

Arab Univ. J. Agric. Sci., 16(1), 2008 
These results are in good agreement with those reported by Abdel-Ghani et al (1997). Furthermore, according to the effect of harvesting time on the minerals content, it could be concluded that the best results obtained especially, for $\mathrm{Ca}, \mathrm{Fe}$ and $\mathrm{Zn}$ were after 140 and 160 days from planting for all varieties.

\section{3- Chemical composition of yellow flesh varie- ties}

Four yellow flesh sweet potato varieties, the more suitable to grow under the Egyptian conditions, namely, JAPON TRESMESINO, LO 323, TAINUNG 64 and BEAUREGARD were examined to evaluate their chemical characteristics and the obtained results are illustrated in Table (3). Both total solids and total soluble solids contents decreased with increasing the harvesting time for all varieties. TAINUNG 64 variety had the highest content of reducing sugar $(28.16 \%)$, followed by JAPON TRESMESINO (22.50\%). Starch and total carbohydrate contents also decreased gradually with increasing the harvesting time, as well as, both LO 323 and BEAUREGARD varieties recorded the highest levels $(66.61 ; 66.24 \%$ and $74.01 ; 73.60 \%$, respectively). On contrast, increasing trend of crude fibers content of all varieties was in parallel with increasing the harvesting time and the highest levels (11.74 and $11.24 \%)$, were found in JAPON TRESMESINO and LO 323 varieties (Table, 3). From the aforementioned data, it was also found that there were small differences in lipid and protein contents of all sweet potatoes ranging from 2.15 to 3.37 and 5.98 to $8.01 \%$, respectively. TAINUNG 64 variety had the highest content of protein $(8.01 \%)$, followed by JAPON TRESMESINO variety $(7.77 \%)$. Decreasing trends of ascorbic acid content of all varieties was in parallel with increasing the harvesting time and the highest levels (9.01 and $8.42 \mathrm{mg} / 100 \mathrm{gm})$, were found in TAINUNG 64 and LO 323 varieties. Concerning total carotenoids content, all yellow flesh sweet potato varieties could be considered as a good source of total carotenoids which increased with increasing the harvesting time. Both TAINUNG 64 and LO 323 varieties recorded the highest levels of total carotenoids (270.30 and $255.80 \mathrm{mg} / 100 \mathrm{gm}$, respectively). Furthermore, the $\beta$-carotene content ranged from 7.534 to $13.452 \mathrm{mg} / 100 \mathrm{gm}$ (Table, 3). So, the highest values of the calculated Retinol Equivalent (R.E.) (2246.48; 2125.91 and 1883.26, respectively), were recorded for TAINUNG 64; LO 323 and
BEAUREGARD varieties. The aforementioned results are in good agreement with those reported by Abdel-Ghani et al (1997 \& 2001) and Zaki (2000 \& 2007).

Finally, from the data presented in Table (3), it could be clearly concluded that yellow flesh sweet potatoes have been recognized as valuable sources of carbohydrates, protein, dietary fibers and could be considered as good sources for both ascorbic acid and total carotenoids. Moreover, TAINUNG 64 and LO 323 varieties have been recognized as good sources of $\beta$-carotene (provitamin $\mathrm{A}$ ), one of the most important nutrients for human nutrition.

\section{4- Minerals content of selected yellow flesh varieties}

The effect of harvesting time on minerals content of selected yellow flesh sweet potatoes are illustrated in Table (4). Potassium was the main element in all the tested varieties being found in high level compared with the other presented elements. But, its level decreased with increasing the harvesting time. These results are in accordance with those reported by Mohamed (1997) and Rashwan (1998). From the data presented in the same table, it could be noticed that 140 days was the best harvesting time after planting as it recorded the highest levels of $\mathrm{Ca}, \mathrm{Fe}$ and $\mathrm{Mn}$ being 79.06 to $111.59 ; 23.25$ to 96.33 and 18.40 to 22.70 $\mathrm{mg} / 100 \mathrm{gm}$, respectively for all yellow varieties. TAINUNG 64 variety had the highest levels of $\mathrm{Ca}, \mathrm{Fe}, \mathrm{Mn}$ and $\mathrm{Zn}$ followed by JAPON TRESMESINO and BEAUREGARD then LO323 varieties. Furthermore, TAINUNG 64 variety recorded the highest level of $\mathrm{Zn}(5.56 \mathrm{mg} / 100 \mathrm{gm})$, after 160 days from planting as the best harvesting time. Generally, yellow flesh sweet potatoes were characterized by high levels of ash and some minerals contents (especially, calcium, iron and manganese) compared with then presented in creamy flesh sweet potato varieties. So, these varieties could be considered as valuable sources of most important minerals with adequate amounts for human nutrition.

Finally, it could be concluded that the most suitable harvesting time for yellow sweet potato varieties was 140 days from planting, which recorded the highest levels of essential mineral elements. On the other hand, TAINUNG 64 variety was considered the best one compared to the other examined varites. 


\section{2- Sensory evaluation of sweet potato products}

Three technological processing i.e., frying, blanching and baking processes were used to evaluate the suitability of selected sweet potato varieties for processing. Fried, blanched and baked sweet potato products were organoleptically evaluated for crispness, freshness, color, taste and odor and the results are illustrated in Tables (5 \& 6). From the data presented in these tables, it could be observed that the KEMB 37, creamy flesh sweet potatoes, recorded the highest scores for all organoleptic properties followed by SANTO AMARA variety. Blanched SANTO AMARA and KEMB 37 varieties showed the highest palatability and acceptability scores, moreover, they were preferred by the panelists compared with fried and baked products of the same varieties. From the data presented in Tables ( 5 \& 6), it could be concluded that the yellow flesh sweet potatoes, TAINUNG 64 and BEAUREGARD were the main varieties having the highest scores of all sensory properties especially, the blanched products than the fried and baked ones. On the other hand, fried TAINUNG 64 variety was the best acceptable one having the overall scores $(7,5.857,8.29$, 7.79 and 6.14 for crispness, freshness, color, taste and odor, respectively) compared with those of the other fried sweet potato varieties. Moreover, a positive correlation has been existed between the increasing total carotenoids content of TAINUNG 64 and BEAUREGARD varieties and the improving color, as well as the acceptability of these products compared with those of other yellow flesh sweet potato varieties.

Finally, from the data presented in Tables (5 \& 6), it could be concluded that the best four varieties suitable for processing and have good quality attributes could be ranked in a descending order were SANTO AMARA and KEMB 37 as creamy flesh sweet potato varieties and TAINUNG 64 and BEAUREGARD as yellow flesh sweet potato varieties. Moreover, these varieties could be successfully used in the production of new and untraditional sweet potato products.

\section{REFERENCES}

Anonymous (1980). National Research Council ( NRC) National Academy of Science. Food and Nutrition Board. Recommended Daily Allowances. Rev. Ed. 9, Washington, D.C., C.F. Abdel-Magied Mona M. et al (1992).
A.O.A.C. (2000). Official Methods of Analysis of the "Association of Official Analytical Chemisit". 15th Ed. Arlington Virgenia U. S. A. Abdel-Ghani Thoraya; M.H. EL-Saidawy; Hemmat I. Mattuk and A.M. Nezam EL-Din (1997). Untraditional products of sweet potatoes. Egypt. J. Appl. Sci., 12(5): 217-237.

Abdel- Ghani Thoraya; K.H. Tolba and Afaf T. Kasim (2001). Chemical and technological studies on new sweet potato varieties. Minufiya J. Agric. Res., 26(2): 485-495.

Abdel- Magied Mona M.; A. Abdel-Hafez and A.W. Wareed (1992). Chemical and organoleptical evaluation of sweet potato candies products. Bull. Fac. of Agric., Univ. of Cairo, 43(1): 6586.

James, C.S. (1995). Analytical Chemistry of Foods. $1^{\text {st }}$ Ed., Chap.6, pp. 60-85\& 353, General Food Studies, The Alden Press, Oxford, UK.

Kasai, M.; N. Okamoto; K. Hatne and A. Shimada (1997). Role of calcium and magnesium ions in the hardening of pressure-treated root vegetables. J. Agric. Food Chem. 45: 599-601.

Lindley, M.G.; P.K. Beyts; I. Caanales and F. Borrego (1993). Flavor modifying characteristics of the intense sweetener neohesperidin dihydrochalcone. J. Food Sci. 58: 592-601.

Mohamed Safia E. (1997). Chemical and technological studies on new sweet potatoes. Egypt. J. Food Sci. 25 (2-3):231-243.

Picha, D.H. (1985). Crude protein, minerals and total carotenoids in sweet potatoes. J. of Food Sci. 50: 1768-1769.

Pupin, A.M.; M.J. Dennis and M.C. Toledo (1999). HPLC analysis of carotenoids in orange juice. Food Chem. 64: 269-275.

Ranganna, S. (1979). Handbook of Analysis and Quality Control for Fruit and Vegetable Products. $2^{\text {nd }}$ Ed. Chapter 28, pp. 888-924, Fruit Juices, Concentrates and Beverages. Tata Mc Graw- Hill Publishing Co., Limited, New Delhi.

Rashwan, M.R.A. (1998). Effect of cooking methods on the nutritional value and microstructure properties of two varieties of Egyptian sweet potatoes. J. Agric. Sci. Mansoura Univ. 23(10): 4487-4495.

Ruel, G.; Sonia P.; C. Patrick; L. Benoít and C. Charles (2005). Changes in plasma antioxidant capacity and oxidized low density lipoprotein levels in men after short- term cranberry juice. Metabolism 54(6): 856-861.

Steel, R.G. and T.H. Torrie (1980). Principles and Procedures of Statistics. Abiometrical Ap- 
proach. McGraw Hill Book Comp., Inc., New York, USA.

Tavani, A. and C. La Vecchia (1995). Fruit and vegetable consumption and cancer risk in a Mediterranean population. Am. J. Clin. Nutr. 61: 1374 $-1377$.

Walter, JR.W.M. and M.W. Hoover (1986). Preparation, evaluation and analysis of a frenchfry- type product from sweet potatoes. J. of Food Sci. 51(4): 967-970.
Woolfe, J.A. (1992). Sweet Potato: an Untapped Food Resource. Cambridge, U.K., Cambridge University Press, C.F. Zaki, Sahar M. (2000).

Zaki, Sahar M. (2000). Technological and Biological Studies on Carrot and Sweet Potato. pp. 245-254, Ph.D. Thesis, Fac. of Agric., Cairo Univ., Egypt.

Zaki, Sahar M. (2007). Effect of osmotic and conventional dehydration on quality of some fruits and vegetables. J. Agric. Sci. Mansoura Univ. 32(2):1179 -1201.
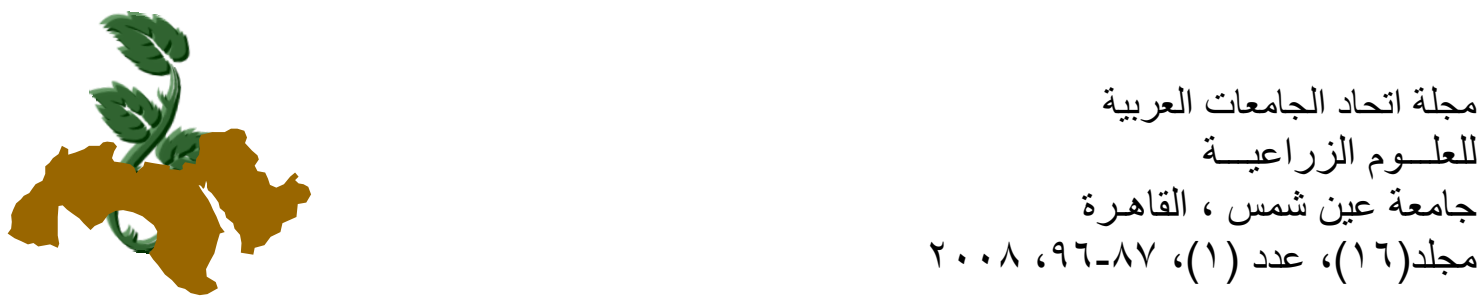

التقييم الكيماوي والتكنولوجي لبعض أصناف البطاطا

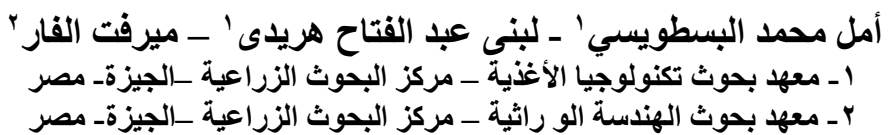

اللون تميزت بأنها مصدر جيد لكل من الكربوهيدرات

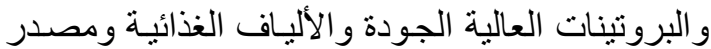

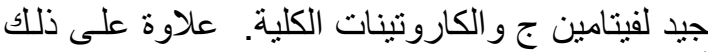

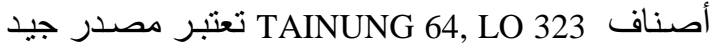
للبيتا كاروتين (مولد فيتامين أ) الهام في تغذية الإنسـان

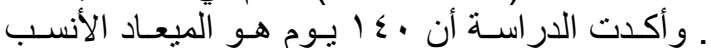

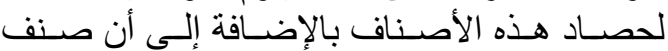

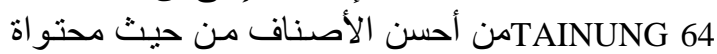

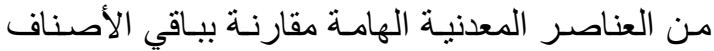

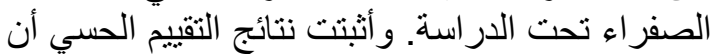

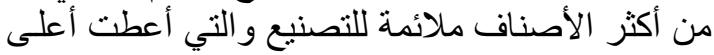

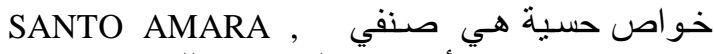
KEMB 37 TAINUNG 64 الصفر اء اللون هذا وبالتالي من الممكن استخدام هذه من الاصن الأصناف بنجاح في إنتاج منتجات جديدة و غير تقليديـة من البطاطا .
يهدف هـذا البحث إلـى تقيهم الخــواص الكيميائيسة لعدد ثماني أصناف جديدة من البطاطسا هي 74-228, SANTO AMARA, NC 1525 and KEMB 37 كريمي اللون و JAPON TRESMESINO, LO 323, TAINUNG 64 and BEAUREGARD أو برتقالية اللون هذا بالإضافة إلى در اسة مدى ملائمة

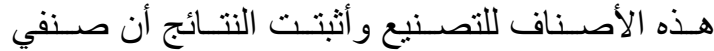
SANTO AMARA , KEMB 37

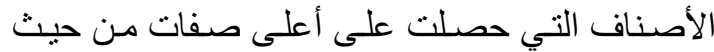

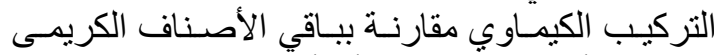

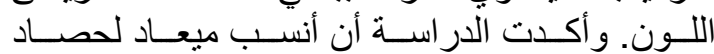

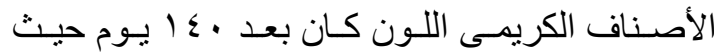

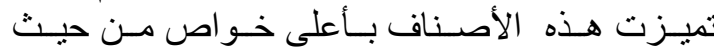
لتركيب الكيماوي. كذلك تحنوى جميع الأصناف ذات ذات

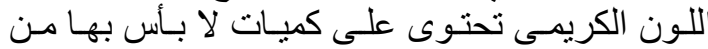

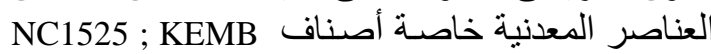
37 ثم صنف SANTO AMARA CEMSA 74-228

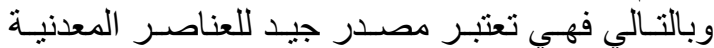

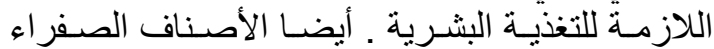

أ.د نبيه عبد الحميد إبراهيم تحكيم: أ.د عصام عثمان فايد 